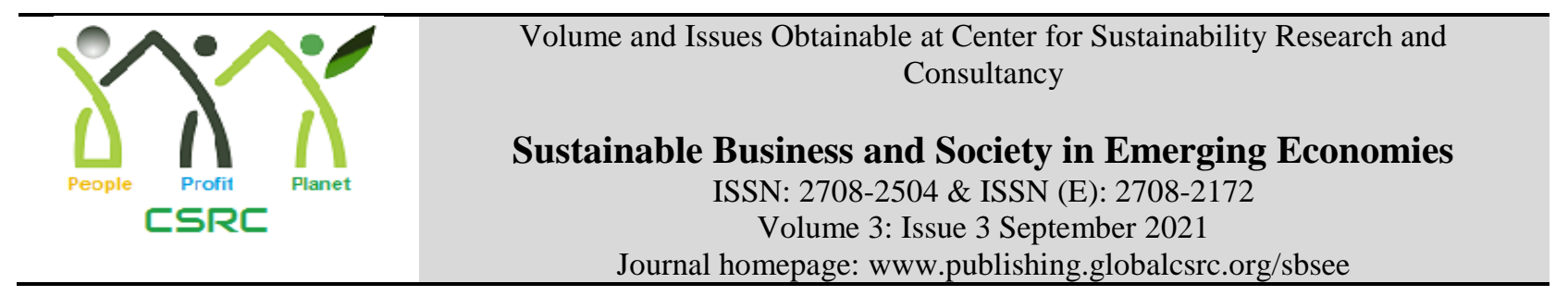

\title{
Impact of Cloud Based Accounting Finance Mechanism with Mediating Effect of Innovative Work Behavior on Business Performance
}

Gohar Mahmood, Department of Commerce, Bahauddin Zakariya University, Multan,Pakistan

*Zainab, Putra Business School, Malaysia

Qaisar Maqbool Khan, Department of Commerce, Bahauddin Zakariya University, Multan, Pakistan

Sadia Munir, Government College Women University, Faisalabad, Pakistan

*Corresponding author's email address: zainabasif1999@gmail.com

ARTICLE DETAILS

History

Revised format: Aug 2021

Available Online: Sep 2021

\section{Keywords}

Cloud, Accounting/Finance,

Innovative work behavior,

Business performance

\section{JEL Classification}

$M 1, M 15$

M4, M41

\section{ABSTRACT}

Purpose: The motivation behind this study is to investigate how the practical implementation of cloud-based accounting/finance mechanism effects business performance with a mediating effect of innovative work behavior among the employees of banking sector.

Design/Methodology: To explore the relationship between the independent, dependent and mediating variables questionnaire method is used. The main view of study is how cloud-based accounting/finance mechanism influences business performance in banks along with the impact of innovative work behavior on business performance. Data collected from 280 managerial level employees of different banks in Faisalabad division.

Findings: This study indicates that cloud-based accounting/finance mechanism has a positive and significant impact on business performance. Innovative work behavior is strengthening the relationship between cloud-based accounting/finance mechanism with business performance. In the presence of innovative work behavior the impact of independent variable considered significant and in more strength. Moreover, this study recommends that firms should focus on innovative work behavior in order to increase their business performance.

Research limitations/implications: The findings suggest that furthermore detailed research is required to explore the effects of cloud-based accounting/finance mechanism and innovative work behavior on business performance.

(C) 2021 The authors, under a Creative Commons AttributionNonCommercial- 4.0

Recommended citation: Mahmood, G., Zainab., Munir, S., Khan, MQ., (2021). Impact of Cloud Based Accounting Finance Mechanism with Mediating Effect of Innovative Work Behavior on Business Performance. Sustainable Business and Society in Emerging Economies, 3 (3), 243-252.

\section{Introduction}

World is a place of diverse culture and technology and due to globalization and internet widespread the 
emergence of cloud-based accounting/finance mechanism occurred. Globalization transformed and revolutionized the world's business and Cloud based accounting/finance mechanism provides the base for acceleration and flexibility in business (Vijai, 2020). Due to high competition and globally indulged business trend, it is very challenging for the businesses to put efforts for the improvement of strategic agility and reduction of the complexities of business operations to sustain their business competence (Tadapaneni, 2020). Therefore, cloud computing in an innovative way is a best solution to provide various on demand IT services to multiple clients by using internet technologies (Sharma, 2020). The main stakeholders of this technology are the providers and consumers. The consumers own use and keep a check on systems upgrading and maintaining while the providers deal with systems sales its installation providing license to the owner and consultants. Cloud computing has the tendency to change and add new roles for the stakeholders (Alezadeh, 2020). Due to the use of cloud computing stress is reduced on IT departments because of new innovative applications which reduced the system maintenance time and improve the business performance. Almost all cloud computing companies now a day are dealing as a large-scale data centers and having a latest infrastructure providing cloud computing services to third parties (Amron, 2019). Among various cloud computing service providers, it is observed that area of specialization is developed related to different components like software, platform and infrastructure that make the cloud computing infrastructure more efficient (Sudhakar, 2014). According to various studies, enablers are the key players and having an important role to facilitate the businesses in order to sell their products and services and also in adoption and use of cloud computing infrastructure (Thabit, 2019). It is a great hurdle so this time yet many of the cloud computing infrastructure and service providers having lack of competencies to interact with their client businesses and its application in true spirit and according to researchers in future this problem can be reduced with the important role of enablers (Oredo, 2019). According to the (Quasim, 2019) innovation is a tool that is meant to be different and distinct and these are the innovative ideas that gains money for business and becomes a creative entity. When an employee adds newness to ideas, improvement in processes and products than this individual behavior is called innovative work behavior. Due to this act of employees the productivity and innovation in products increased results in greater business performance (Singh, 2018). When it is specifically met with the problems of the firm and organization it is supposed that the innovative work behavior process should act and resolve the problems and set new lines of work for the workers and management (Tripathi, 2018). The real cloud computing application in the business environment has recently been emerged (Stewart, 2021) and few studies have talked about this new business phenomenon and with the evolution of cloud computing and the benefits it is providing new areas of research will be opened to researchers (Asadi, 2017).

In this study, the focus is on the cloud computing infrastructure which validates its economic perspective for the businesses which are interested in the adoption of cloud computing infrastructure. Furthermore, the impact of economic perspective due the implementation cloud computing environment will also be investigated in this study. Various studies both academic and industry shows the significant economic perspective impact on business performance due to the use of cloud computing infrastructure (Devi, 2021). This core idea of use of cloud computing infrastructure investigates the firm's market value which is impacted after the adoption of this new innovative idea (Tiwari, 2021). There is significant and positive increase in the market value of the firms who adopted the cloud computing environment. However, there are significant differences due to the level of adoption of cloud computing infrastructure, firm size and industry sector on the market returns of the. It is therefore very easy and useful for the firms whether, when and how to opt the cloud-based accounting/finance mechanism in order to maximize the business worth (Padmaja, 2021). Last few years has seen the massive convergence of knowledge by using cloud because knowledge has become more accessible through cloud. Furthermore, open data initiatives are more prominent now for a variety of uses that includes research purposes and document preservation by creating the online digitalized material (Nguyen, 2021). The amount of born digital data gives rise to the need of management of the corresponding information in such a way that ensures the exploitation of available data sources. Previous research says that the impact of cloud-based accounting/finance mechanism with mediating effect of innovative work behavior might also have 
impact on business performance (Asadi, 2016). The reason to check the impact of independent variable on dependent variable with mediating variable is that if firms adopt Cloud based accounting/finance mechanism it has the potential to strengthen all the two elements of the study in a positive and significant manner (Keskar, 2016). The findings of this research will contribute to develop economic contextual dimensions that help to increase growth of businesses. These sets of variables are limited study in case of Pakistan. The beginning of cloud computing has enabled firms of varying of sizes to upgraded bookkeeping, equipment and systems administration limit, without a relating necessity of capital speculation. This study focused that how much effects of Cloud based accounting/finance mechanism having a positive and significant impact on business performance which help to increase firm growth. Furthermore, innovative work behavior has mediating the relationship of independent variables and dependent variable. These research questions and objectives are helped to improve to measure the ability, capability, information, knowledge and attainability of relevant fields. Innovative work behavior has been strengthening the relationship between Cloud based accounting/finance mechanism with business performance.

\section{Literature Review}

Cloud computing generally refers to the attentiveness of all parts of an organization. Computer resources shared and provide better work environment (Elzamly, 2016). Companies were also using information systems for good performance (Kouser, et al 2011). Cloud computing access is generally restricted to relevant authorized users through internet-supported devices (Awadallah, 2016). By using cloud computing organization gain potential assistances including the capability to measure suitability of global data system according to information technology desires and removes obstacles to innovation and cost consumed, easy access to software updating (Elzamly, 2019). Cloud computing just facilitates larger organizations for the significant necessities of capital investment but now a days it simplifies the utilization of influential information technology for smaller organization (Alezadeh, 2020). Besides, software computing can possibly free up rare assets in every aspect of a company's business, including accounting/finance (Messabia, 2019). Such assets would some way or other are consumed fundamentally on IT upkeep instead of being utilized for more vital and esteem making purposes (Thabit, 2019). All the organizations using cloud computing have the ability to cope with the data variation in all perspectives like at the maximum and minimum level (Baker, 2019). Furthermore, all the organizations should change their infrastructure according to changing market needs which is also very helpful to become more responsive and cost efficient with quality of services (Bose, 2019). Due to innovation cloud computing-based applications and software and more easy, quick and more responsive as compared to conventional and outdated systems (Padmaja, 2021). Cloud computing infrastructure is built on the principle of economies of large scales production which reduces the cost and enables the firm to become more competitive and cost efficient with no capital investment (Huttunen, 2019). Now a days, the firms at all levels are converting from conventional IT methods which are expensive to cloud computing which is very cost efficient and attractive for organizations (Asadi, 2020). Also, in building up the innovation work behavior, to give harmony is imperative. Since, while imaginative idea or development is an individual action alone, making advancement and executing this development is an aggregate achievement (Niazmand, 2015).

\section{Model}

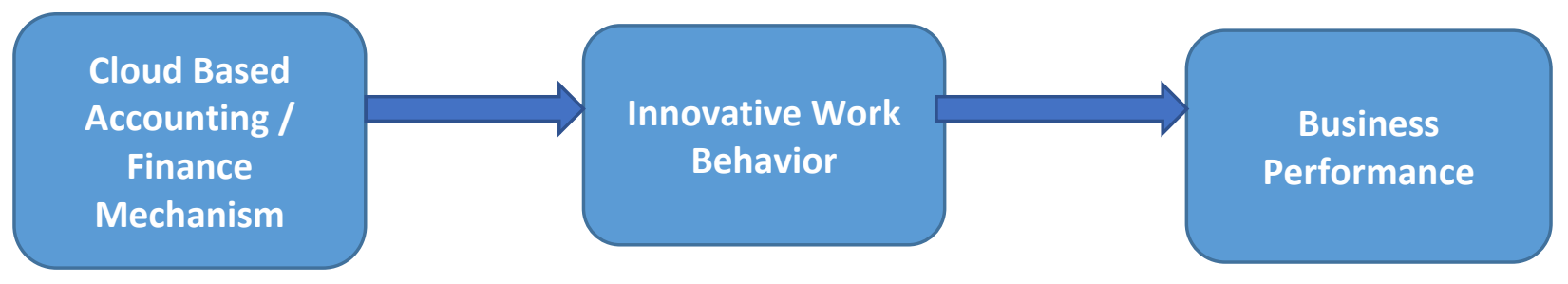




\section{Hypothesis}

H1: Cloud based accounting/finance mechanism has significant impact on innovative work behavior

H2: Innovative work behavior has significant impact on business performance

H3: Cloud based accounting/finance mechanism has significant impact on business performance using innovative work behavior as mediator.

\section{Methodolgy}

The proposed study at hand is quantitative in nature. Collection of data is by using survey method through questionnaires, which are distributed among the respondents of the selected organizations working in banking sector of Pakistan. Banking organizations providing cloud-based services in banking sector of Pakistan will be taken as the unit of analysis. The entire population for this study based on the employees working at different managerial levels (Managers, Operational Managers) at different branches of banks based in Faisalabad Division. The 300 questionnaires collected as a sample for this study due to time constraint. Factor analysis, correlation, regression and reliability analysis is done on the collected data by using SPSS. The questionnaire is based on the 47 items with 7-point likert scale.

\section{Demographic variable}

The demographic variable characteristic has been stated as under.

\section{Table 01 Gender \\ Male, Female}

\begin{tabular}{|ll|l|l|l|l|}
\hline & & Frequency & Percent & Valid Percent & Cumulative Percent \\
\hline \multirow{4}{*}{ Valid } & Male & 240 & 85.7 & 85.7 & 85.7 \\
& $\begin{array}{l}\text { Female } \\
\text { Total }\end{array}$ & 40 & 14.3 & 14.3 & 100.0 \\
\hline
\end{tabular}

Table 01 shows the results of demographic variable with the help of gender. The study describes the total frequency 280 show among the male and female. The Male frequency is 240 and cumulative $\%$ is 85 . The female frequency is 40 and cumulative $\%$ is 100 .

Table 02 Qualification

Intermediate, Graduation, Masters

\begin{tabular}{|ll|l|l|l|l|}
\hline & & Frequency & Percent & Valid Percent & Cumulative Percent \\
\hline \multirow{4}{*}{ Valid } & Graduation & 96 & 34.3 & 34.3 & 34.3 \\
& Masters & 184 & 65.7 & 65.7 & 100.0 \\
\hline
\end{tabular}

Table 02 shows the results of demographic variable with the help of Qualification. The study describes the total frequency 280 show among the intermediate, Graduation, and Masters. The graduation level frequency is 96 and cumulative \% 34.3. The master level frequency is 184 and cumulative $\% 100$.

Table 03 Designation

Branch Manager, Operational Manager

\begin{tabular}{|l|l|l|l|l|}
\hline & Frequency & Percent & Valid Percent & Cumulative Percent \\
\hline Valid Branch Manager & 35 & 12.5 & 12.5 & 12.5
\end{tabular}




\begin{tabular}{l|l|l|l|l} 
Operational Manager & 245 & 87.5 & 87.5 & 100.0 \\
Total & 280 & 100.0 & 100.0 & \\
\hline
\end{tabular}

Table 03 shows the results of demographic variable with the help of designation. The study describes the total frequency 280 show among the Branch manager and operation manager. The branch manager frequency is 35 and cumulative $\%$ 12.5. The operation manager frequency is 245 and cumulative $\% 100$.

Table 04 Sector

Bank Names

\begin{tabular}{|l|l|l|l|l|}
\hline & Frequency & Percent & Valid Percent & Cumulative Percent \\
\hline MCB & 36 & 12.9 & 12.9 & 12.9 \\
HBL & 20 & 7.1 & 7.1 & 20.0 \\
ALFALAH & 67 & 23.9 & 23.9 & 43.9 \\
SILK & 6 & 2.1 & 2.1 & 46.1 \\
STANDARD CHARTERED & 20 & 7.1 & 7.1 & 53.2 \\
SUMMIT & 13 & 4.6 & 4.6 & 57.9 \\
JS & 12 & 4.3 & 4.3 & 62.1 \\
MEEZAN & 19 & 6.8 & 6.8 & 68.9 \\
FAISAL & 18 & 6.4 & 6.4 & 75.4 \\
NATIONAL & 15 & 5.4 & 5.4 & 80.7 \\
PUNJAB & 29 & 10.4 & 10.4 & 91.1 \\
UBL & 25 & 8.9 & 8.9 & 100.0 \\
Total & 280 & 100.0 & 100.0 & \\
\hline
\end{tabular}

Table 04 shows the results of demographic variable with the help of Sector. The study describes the total frequency 280 banks of Pakistan.

Table 05 Experience

Less than 1year, more than1to3Years, more than 4to5years

\begin{tabular}{|ll|l|l|l|l|}
\hline & Frequency & Percent & Valid Percent & Cumulative Percent \\
\hline \multirow{4}{*}{ Valid } & Less than 1 year & 16 & 5.7 & 5.7 & 5.7 \\
& More than 1 to 3 Year & 72 & 25.7 & 25.7 & 31.4 \\
& More than 4 to 5 years & 192 & 68.6 & 68.6 & 100.0 \\
Total & 280 & 100.0 & 100.0 & \\
\hline
\end{tabular}

Table 05 shows the results of demographic variable with the help of Experience. The study describes the total frequency 280. The variable divided into three options. The employees having experience less than 1 -year frequency is 16 . The Second frequency shows 72 in case of more than 1 to 3 years' experience. The third frequency shows 192 in case of less than 4 year to 5 years.

\section{Empirical Results Analysis}

\section{Table 06 Factor Analysis of Cloud Based Accounting/Finance Mechanism}

Table 06 shows one factor solution of Cloud based Accounting/Finance Infrastructure. Total variance explained is 55.131 cumulative \% and only one item has a low factor loading which has been excluded from the study for more precise results. Generally KMO value of 0.50 is considered as acceptable value while in this study Cloud based Accounting/Finance Infrastructure has a KMO value of 0.811 that is 
significant and above the minimum acceptable level of 0.50 .

\begin{tabular}{|c|c|}
\hline \multirow{2}{*}{$\begin{array}{l}\text { Cloud based accounting/finance mechanism }(\mathrm{KMO}=\mathbf{. 8 1 1}) \\
\text { (CBAFI) }\end{array}$} & Factor \\
\hline & Loading \\
\hline 1. Our daily accounting tasks more standardized due to CBAFI. & .657 \\
\hline 2. Our accounting processes are simplified due to CBAFI. & .756 \\
\hline 3. All the staff members are at great ease to perform all accounting tasks due to CBAFI. & .751 \\
\hline $\begin{array}{l}\text { 4. The communication of accounting rules and procedures to the new members of } \\
\text { accounting staff is easier due to CBAFI. }\end{array}$ & .802 \\
\hline 5. It is easier to documents accounting procedures due to CBAFI. & .734 \\
\hline 6. It is easier to adapt accounting procedures due to CBAFI & .766 \\
\hline $\begin{array}{l}\text { 7. It is very easy to adopt and implement the accounting and finance systems to other } \\
\text { parts/branches of the organization due to CBAFI. }\end{array}$ & .725 \\
\hline Cumulative percentage of the variance explained $(\%)$ & $55.131 \%$ \\
\hline
\end{tabular}

\section{Table 07 Factor Analysis of Innovative Work Behavior}

Table 07 shows one factor solution of Innovative Work Behavior. Total variance explained is 64.685 cumulative $\%$ and no item has a low factor loading that why no item has excluded from the study for more precise results. Generally KMO value of 0.50 is considered as acceptable value while in this study innovative work behavior has a KMO value of 0.788 that is significant and above the minimum acceptable level of 0.50 .

\begin{tabular}{|r|l|}
\hline \multicolumn{2}{|l|}{ Table 07 Factor Analysis of Innovative Work Behavior } \\
\hline Innovative Work Behavior (KMO=.788) & Factor \\
\cline { 2 - 3 } & Loading \\
\hline 1. In my bank my opinion is asked by my leadership. & .860 \\
\hline $2 . \quad \begin{array}{l}\text { In my bank my leadership inquires suggestion from my side to carry out day by day } \\
\text { task. }\end{array}$ & .815 \\
\hline $3 . \quad \begin{array}{l}\text { In my bank my leadership consults with me before planning and implementing any } \\
\text { kind of changes. }\end{array}$ & .817 \\
\hline $4 . \quad \begin{array}{l}\text { In my bank my leadership warmly welcome my ideas for long term planning and } \\
\text { future directions. }\end{array}$ & .875 \\
\hline $5 . \quad \begin{array}{l}\text { In my bank my leadership has fully authorized me to set my own goals and objectives } \\
\text { align with the vision and mission of the bank. }\end{array}$ & .778 \\
\hline $6 . \quad \begin{array}{l}\text { In my bank my leadership gives me considerable opportunities for independence and } \\
\text { freedom }\end{array}$ & .662 \\
\hline Cumulative percentage of the variance explained (\%) & $64.685 \%$ \\
\hline
\end{tabular}

\section{Table 08 Factor Analysis of Firm Performance}

Table 08 shows one factor solution of Firm Performance. Total variance explained is 62.587 cumulative $\%$ and no item has a low factor loading that why no item has excluded from the study for more precise results. Generally, KMO value of 0.50 is considered as acceptable value while in this study innovative work behavior has a KMO value of 0.864 that is significant and above the minimum acceptable level of 0.50 .

\begin{tabular}{|c|l|}
\hline \multicolumn{2}{|l|}{ Table 08 Factor Analysis of Firm Performance } \\
\hline Firm Performance (KMO=.864) & Factor \\
\cline { 3 - 3 } & Loading \\
\hline 1. $\quad$ Enhance shareholder/business value & .855 \\
\hline $2 . \quad$ Enhance our corporate reputation & .840 \\
\hline $3 . \quad$ Outperform our main trading rivals & .816 \\
\hline $4 . \quad$ Enhance our strategic decision-making & .796 \\
\hline 5. Attain a competitive advantage & .776 \\
\hline $6 . \quad$ Improve our overall business performance & .645 \\
\hline Cumulative percentage of the variance explained (\%) & $62.587 \%$ \\
\hline
\end{tabular}




\section{Table 09 Correlation Analysis}

Table 09 shows the correlation analysis of the three variables which are Cloud based accounting/finance mechanism, innovative work behavior and business performance; so, for this purpose correlation analysis technique is used in order to measure the correlation between these three study variables. The results of correlation analysis shows that there is a strong positive significant relationship between the each factor of Cloud based accounting/finance and business performance using innovative work behavior as a mediator in this $\operatorname{study}(\mathrm{p}<0.001)$.

Table 09: Correlation Analysis

\begin{tabular}{|ll|l|l|l|}
\hline & & AVGCBAF & AVGIWB & AVGBP \\
\hline \multirow{2}{*}{ AVGCB } & Pearson Correlation & 1 & $.497^{* *}$ & $.634^{* *}$ \\
AF & Sig. (2-tailed) & .000 & .000 \\
& N & & 280 & 280 \\
AVGIW & Pearson Correlation & & $.586^{* *}$ \\
B & Sig. (2-tailed) & & .000 \\
& N & & & 280 \\
AVGBP & Pearson Correlation & & & 1 \\
& Sig. (2-tailed) & & & \\
\hline
\end{tabular}

Note: **Correlation is significant at the 0.01 level (2-tailed). (CBAF) is Cloud based accounting/finance, (IWB) Innovative work behavior, and (BP) Business performance.

\section{Table 10 Reliability Analysis}

Table 10 shows the reliability analysis of the three variables which are Cloud based accounting/finance mechanism, innovative work behavior and business performance; For the expression of the results of the study the values of means, standard deviations and alpha values are given in the table 10. Each factor of Cloud based accounting/finance mechanism, innovative work behavior and business performance has been found in significant reliability with each other $(\mathrm{p}<0.001)$. The rating of means given in this study is above two for each factor that is rated high and all the study variables have acceptable and reliable Cronbach's alpha values, which are given here. i.e., CBAF $(\alpha=0.863)$, IWB $(\alpha=0.887)$ and BP $(\alpha=0.878)$

Table 10: Reliability Analysis

\begin{tabular}{|lccc|}
\hline & Mean & S.D & Alpha \\
CBAF & 2.7964 & 1.16744 & 0.863 \\
IWB & 3.1107 & 1.36442 & 0.887 \\
BP & 2.6327 & 1.21804 & 0.878 \\
& & & \\
\hline
\end{tabular}

Note: (CBAF) Cloud based accounting/finance mechanism, (IWB) Innovative work behavior, (BP) Business performance.

\section{Regression Analysis}

In order to test the hypotheses of this study regression analysis has been done with the help of SPSS 23 software. There are two tables $(11,12)$ which are given in order to discuss the results. As shown in Table 11, Adjusted $\mathrm{R}^{2}$ value is 0.244 , which explains the variation in Cloud based accounting/finance, mechanism and Innovative Work Behavior is explained up to $24.4 \%$ respectively. Standard regression coefficient between Cloud based accounting/finance mechanism and Innovative Work behavior is significant $(\beta=1.487, \mathrm{p}<.001)$ with significant $\mathrm{T}$ value $(8.069, \mathrm{p}<.001)$ and $\mathrm{F}$ value $(91.073, \mathrm{p}<.001)$. Hence, hypotheses $\mathrm{H} 1$ supported but in a very weak relation.

Table 11: Regression Analysis of Cloud based accounting/finance mechanism and Innovative work behavior 


\begin{tabular}{|c|c|c|c|c|c|c|}
\hline Model & $\mathrm{R}$ & R Square & $\begin{array}{ll}\text { Adjusted } & \mathrm{R} \\
\text { Square } & \end{array}$ & $\begin{array}{l}\text { Std. Error of the } \\
\text { Estimate }\end{array}$ & $\mathrm{F}$ & Sig. \\
\hline 1 & $.497^{\mathrm{a}}$ & .247 & .244 & 1.18630 & 91.073 & $.000^{\mathrm{a}}$ \\
\hline \multirow{2}{*}{\multicolumn{2}{|c|}{ Model }} & \multicolumn{2}{|c|}{ Unstandardized Coefficients } & $\begin{array}{l}\text { Standardized } \\
\text { Coefficients }\end{array}$ & $\mathrm{T}$ & Sig. \\
\hline & & $\mathrm{B}$ & Std. Error & Beta & & \\
\hline \multirow[t]{2}{*}{1} & Constant & 1.487 & .184 & & 8.069 & .000 \\
\hline & Avg CBAF & .581 & .061 & .497 & 9.543 & .000 \\
\hline
\end{tabular}

a. Dependent Variable: IWB Note: IWB= Innovative Work Behavior, $\mathrm{CBAF}=$ Cloud based accounting/finance mechanism

Table 12 shows the results of Adjusted $\mathrm{R}^{2}$ with a value of 0.693 that means that the variation between the study variables business performance and Cloud based accounting/finance mechanism and mediation of innovative work behavior is $69.3 \%$ respectively. The values of standard regression coefficient of the study variables business performance and cloud-based accounting/finance mechanism is significant and values are given $(\beta=-.028, \mathrm{p}<.001)$ with significant $\mathrm{T}$ value $(-.534 \mathrm{p}<.001)$ and $\mathrm{F}$ value $(210.961$, $\mathrm{p}<.001)$. All the values show that hypotheses $\mathrm{H} 2$ is supported. While the values of standard regression coefficient between Business performance and innovative work behavior is significant and all the values are given $(\beta=.134, \mathrm{p}<.001)$ with significant $\mathrm{T}$ value $(3.214, \mathrm{p}<.001)$ and $\mathrm{F}$ value $(210.961, \mathrm{p}<.001)$. This means that hypotheses $\mathrm{H} 3$ of this study is supported.

\section{Table 12: Regression Analysis of Business Performance and CBAF and IWB}

\begin{tabular}{|c|c|c|c|c|c|c|}
\hline Model & $\mathrm{R}$ & R Square & $\begin{array}{ll}\text { Adjusted } \\
\text { Square }\end{array}$ & $\begin{array}{l}\text { Std. Error of the } \\
\text { Estimate }\end{array}$ & $\mathrm{F}$ & Sig. \\
\hline 1 & $.834^{\mathrm{a}}$ & .696 & .693 & .67485 & 210.961 & $.000^{\mathrm{a}}$ \\
\hline \multirow{2}{*}{\multicolumn{2}{|c|}{ Model }} & \multicolumn{2}{|c|}{ Unstandardized Coefficients } & $\begin{array}{l}\text { Standardized } \\
\text { Coefficients }\end{array}$ & $\mathrm{T}$ & Sig. \\
\hline & & $\mathrm{B}$ & Std. Error & Beta & & \\
\hline \multirow[t]{2}{*}{1} & Constant & 1.361 & .120 & & -.859 & .391 \\
\hline & $\begin{array}{l}\text { Avg CBAF } \\
\text { Avg IWB }\end{array}$ & $\begin{array}{l}-.029 \\
.120\end{array}$ & $\begin{array}{l}.055 \\
.037\end{array}$ & $\begin{array}{l}-.028 \\
.134\end{array}$ & $\begin{array}{r}-.534 \\
3.214\end{array}$ & $\begin{array}{l}.593 \\
.000\end{array}$ \\
\hline
\end{tabular}

a. Dependent Variable: BP Note: BP=Business Performance, $\mathrm{CBAF}=\mathrm{Cloud}$ based accounting/finance mechanism, IWB= Innovative Work Behavior,

\section{Conclusion}

The purpose of this study was to investigate the impact of Cloud based accounting/finance mechanism on business performance through mediating effect of innovative work behavior. Different questions are used to explore this study. Cloud based accounting/finance mechanism have positive influence on business performance. If the firms adopt cloud base accounting and finance infrastructure and also adopt innovative work behavior then there is a great positive increase in business performance in terms of growth and profit. Results show that those firms who have more conscious about innovation and innovative work behavior seem more oriented towards their business growth.

According to the results of this study Cloud based accounting/finance mechanism has positive and significant impact on the business performance and thus the hypothesis $\mathrm{H} 1$ is supported. Innovative work behavior has a positive and significant impact of the business performance and thus the hypothesis $\mathrm{H} 2$ is supported. Cloud based accounting/finance mechanism has a strong and significant impact on business performance through meditating effect of innovative work behavior and thus the hypothesis $\mathrm{H} 3$ is supported and it also proved the same results with many studies that were conducted in different countries and almost on the same sample size. This study only based on banking sector and only private sector commercial banks are the sample of this study. Questionnaire did not cover all aspects of Cloud based accounting/finance mechanism, innovative work behavior and business performance and might be 
possible lot of other factor may positively effect on business performance. Data collection is done by questionnaire it is possible that face-to-face questions related to study will provide more information about the study. The data were collected by only from managerial level bankers who are currently working on theses posts because of ease of access to them. This study leads to number of implications for academic, banking sector and government regulatory bodies. This study will help to banks to overcome their barriers or problems in automation and systematic operations of the business.

This study also indicates some basic areas of Cloud based accounting/finance mechanism for future research, as this study mention in limitations that while unnecessary delay in cloud-based adoption will drastically impact the business performance as it can be seen in the national bank of Pakistan and all other privatized banks business working models. In future with different and other variables study can be conducted to know the effect of variables. Future research may be conduct with other variables to explore the other aspects of this study.

This research study has some limitations while like all other research studies while the very first limitation is that this study is based on one sector of the country that is banking from where all the data is collected for the analysis and check the effect of study variables as suggested by many studies but in different perspectives. The second limitation of this study is related to the small sample size of the study which means that when the sample size will be large it can affect the results of the study in both positive and negative manner. Additionally, data was collected only from the managerial level who has limited usage of computing resources. This study is just focus on the very limited no. of explanatory variables. So therefore, still many other factors that should be considered in order to get the better results.

\section{References}

Alizadeh, A., Chehrehpak, M., Nasr, A. K., \& Zamanifard, S. (2020). An empirical study on effective factors on adoption of cloud computing in electronic banking: a case study of Iran banking sector. International Journal of Business Information Systems, 33(3), 408-428.

Amron, M. T., Ibrahim, R., Bakar, N. A. A., \& Chuprat, S. (2019). Acceptance of cloud computing in the Malaysian public sector: a proposed model. International Journal of Engineering Business Management, 11, 1847979019880709.

Asadi, S., Nilashi, M., Husin, A. R. C., \& Yadegaridehkordi, E. (2017). Customers perspectives on adoption of cloud computing in banking sector. Information Technology and Management, 18(4), 305-330.

Awadallah, N. (2016). Usage of cloud computing in banking system. International Journal of Computer Science Issues (IJCSI), 13(1), 49.

Baker, C., Fratto, D., \& Reiners, L. (2019). Banking on the Cloud. Transactions: Tenn. J. Bus. L., 21, 381.

Bose, R., Chakraborty, S., \& Roy, S. (2019, February). Explaining the workings principle of cloudbased multi-factor authentication architecture on banking sectors. In 2019 Amity International Conference on Artificial Intelligence (AICAI) (pp. 764-768). IEEE.

Devi, A., Therese, M. J., \& Premalatha, G. (2021). Cloud Computing based Intelligent Bank Locker System. In Journal of Physics: Conference Series (Vol. 1717, No. 1, p. 012020). IOP Publishing.

Elzamly, A., Hussin, B., Abu Naser, S., Khanfar, K., Doheir, M., Selamat, A., \& Rashed, A. (2016). A new conceptual framework modelling for cloud computing risk management in banking organizations. International Journal of Grid and Distributed Computing, 9(9), 137-154.

Huttunen, J. E. N. N. I. F. E. R., Jauhiainen, J. A. A. N. A., Lehti, L. A. U. R. A., Nylund, A. N. N. I. N. A., Martikainen, M. I. N. N. A., \& Lehner, O. M. (2019). Big data, cloud computing and data science applications in finance and accounting. ACRN Oxford Journal of Finance and Risk Perspectives, 8, 16-30.

Keskar, M. Y., \& Pandey, N. (2018). Internet banking: a review (2002-2016). Journal of Internet Commerce, 17(3), 310-323. 
Messabia, N., Doheir, M., Mahmoud, A., Bin Hasan Basari, A. S., Abu Selmiya, N., \& Sayed, A. A. (2019). Adoption of Cloud Computing model for Managing e-Banking System in Banking Organizations. International Journal of Advanced Science and Technology, 28(1), 318-326.

Nguyen, N. D. K., \& Ali, I. (2021). Implementation of Cloud Customer Relationship Management in Banking Sector: Strategies, Benefits and Challenges. International Journal of Electronics and Communication Engineering, 15(6), 242-247.

Niazmand, N. (2015). The impact of Cloud Computing in the banking industry resources. International Journal of Information, Security and Systems Management, 4(2), 436-440.

Oredo, J. O., Njihia, J., \& Iraki, X. N. (2019). Adoption of cloud computing by firms in Kenya: The role of institutional Pressures. The African Journal of Information Systems, 11(3), 1

Padmaja, K., \& Seshadri, R. (2021). Analytics on real time security attacks in healthcare, retail and banking applications in the cloud. Evolutionary Intelligence, 14(2), 595-605.

Quasim, M. T., Johri, P., Meraj, M., \& Haider, S. W. (2019). 5V's of big data via cloud computing: uses and importance. Sci. int (Lahore), 31(3), 367-371.

Kouser, R., Rana E.G. \& Shahzad A.F. (2011). Determinants of AIS Effectiveness: Assessment thereof in Pakistan. International Journal of Contemporary Business Studies (IJCBS), Vol: 2(12), pp. 0621.

Kouser, R., Awan, A., Rana E.G. \& Shahzad A.F. (2011) Firm size, leverage and profitability: overriding impact of accounting information system. Business and Management Review (BMR), Vol: 1(10), pp. 58-64.

Singh, M., \& Kumar, D. (2018). REVIEW OF CLOUD COMPUTING.

Sharma, M., Gupta, R., \& Acharya, P. (2020). Factors influencing cloud computing adoption for higher educational institutes in India: a fuzzy AHP approach. International Journal of Information Technology and Management, 19(2-3), 126-150.

Stewart, H. (2021). The hindrance of cloud computing acceptance within the financial sectors in Germany. Information \& Computer Security.

Sudhakar, K., Kumar, G. V., \& Rani, L. S. (2014). A View on Cloud Computing in the Banking Sector.

Tadapaneni, N. R. (2020). Cloud Computing-An Emerging Technology. International Journal of Innovative Science and Research Technology, 5(3).

Thabit, F., Alhomdy, S. A. H., \& Jagtap, S. B. (2019). Toward a Model for Cloud Computing Banking in Yemen. International Journal of Research in Advanced Engineering and Technology, 5(4), 14-18.

Tiwari, S., Bharadwaj, S., \& Joshi, S. (2021). A Study of Impact of Cloud Computing and Artificial Intelligence on Banking Services, Profitability and Operational Benefits. Turkish Journal of Computer and Mathematics Education (TURCOMAT), 12(6), 1617-1627.

Tripathi, S. (2018). Moderating effects of age and experience on the factors influencing the actual usage of cloud computing. Journal of International Technology and Information Management, 27(2), 121-158.

Vijai, C., \& Nivetha, P. (2020). E-commerce on cloud: opportunities and challenges. Advances in Management, 13(3). 